\title{
Increased smooth muscle contractility of intestine in the genetic null of the endothelin ETB receptor: a rat model for long segment Hirschsprung's disease
}

\author{
K-J Won, S Torihashi, M Mitsui-Saito, M Hori, K Sato, T Suzuki, H Ozaki, H Karaki
}

Gut 2002;50:355-360

See end of article for authors' affiliations

Correspondence to:

Dr H Ozaki, Department of Veterinary Pharmacology,

Graduate School of

Agriculture and Life

Sciences, The University of

Tokyo, Bunkyo-ku, Yayoi

1-1-1, Tokyo 113-8657,

Japan; aozaki@

mail.ecc.u-tokyo.ac.jp

Accepted for publication 20 June 2001

\begin{abstract}
Background and aims: The endothelin ETB receptor null rat (ETB(-/-|R) has an intestinal segment without ganglia, and this rat is characterised by intestinal obstruction similar to that observed in human Hirschsprung's disease. In the present study, we have examined the myogenic mechanism responsible for obstruction in the ETB(-/-|R.

Results: The ETB(-/-)R had an enlarged belly and the average lifespan was 18.1 days. The bowel from the rectum to the lower part of the small ileum was constricted whereas the upper region was dilated with faecal stasis and thus presented as megaileum. The constricted muscle segments without ganglia had a greater increase in absolute force when stimulated by carbachol, high $\mathrm{K}^{+}$, and endothelin-1 compared with that of normal siblings. In contrast, in the dilated part with ganglia, the absolute contractile force due to these stimulants in the ETB(-/-)R was not different from that in the $\mathrm{ETB}(+/+)$ R. Such a functional hypertrophy of the musculature was observed in parts of the colon, caecum, and distal ileum without ganglia but not in the part of the proximal ileum and jejunum with ganglia. Morphological study demonstrated that the thickness of the circular and longitudinal muscle layers was greater in the constricted part of the intestine in the ETB(-/- R, and these changes were associated with an increase in the number of smooth muscle cells.

Conclusions: Our findings suggest that both increased contractility of smooth muscle and increased thickness of the intestinal muscular wall may contribute to the intestinal obstruction in the ETB(-/-)R.
\end{abstract}

M otility disorders of the gastrointestinal tract are extremely important in the clinical field because they can lead to systemic diseases. Obstructive intestinal disorders caused by abnormalities of the enteric nerves are observed as an enlargement of the intestine or chronic constipation. It is known that Hirschsprung's disease, which is usually detected during the neonatal period, is the most common developmental obstructive motility disorder of the colon, ${ }^{1}$ and the incidence of Hirschsprung's disease is approximately 1 in 5000 live births. ${ }^{2-4}$ Thus this disease is regarded as an important congenital obstructive disorder in paediatrics. Studies undertaken to further our understanding of the pathogenesis of Hirschsprung's disease have focused on the development of the enteric nervous system (see discussion below).

Such pathological features of the inherited aganglionosis megacolon, present in Hirschsprung's disease, are also commonly found in livestock, including horses and pigs, ${ }^{56}$ and in experimental animals, including rats and mice. A mutant spotted lethal rat with a congenital aganglionic bowel (congenital aganglionosis rat) has been described as progeny of a Wistar-Imamichi female and a wild male rat. ${ }^{7}$ The aganglionosis rat has been found to be genetically lacking the endothelin ETB receptor. ${ }^{8-10}$ This rat is characterised by an aganglionosis intestine and white coat colour, with a small pigmented spot on the head caused by an autosomal recessive gene (sl), ${ }^{10}$ and in most cases showing symptoms of constriction in a longer region of the intestine. ${ }^{72}{ }^{13}$ Heterozygotic rats $(\mathrm{sl} /+)$ however as well as those homozygous for the dominant gene $(+/+)$ appear to be identical both histologically and anatomically. ${ }^{14}$ The ETB $(-/-)$ R, pathophysiologically and histologically, resembles humans showing severe symptoms of long segment Hirschsprung's disease, ${ }^{412}$ which led to its selection as an animal model of intestinal obstructive disease (including human Hirschsprung's disease) in this study.
The pathophysiology of Hirschsprung's disease is obscure even though several morphological and functional abnormalities have been identified. In particular, smooth muscle alterations have yet to be clarified. The experiments carried out in the present study were designed to functionally and morphologically examine the myogenic diversity of the $\operatorname{ETB}(-/-) \mathrm{R}$ and to better characterise an animal model for human long segment Hirschsprung's disease.

\section{MATERIALS AND METHODS}

Muscle preparations and measurement of contraction At approximately 12-15 days of age, rats were killed by a sharp blow to the neck and exsanguination. The whole or some part of the intestine was dissected out and rinsed in physiological salt solution containing (mM): $\mathrm{NaCl}$ 136.9, $\mathrm{KCl} 5.4, \mathrm{CaCl}_{2}$ 1.5, $\mathrm{MgCl}_{2}$ 1.0, $\mathrm{NaHCO}_{3}$ 23.8, EDTA 0.01, and glucose 5.5. This solution was saturated with a $95 \% \mathrm{O}_{2}$ and $5 \% \mathrm{CO}_{2}$ mixture at $37^{\circ} \mathrm{C}, \mathrm{pH}$ 7.4. For measurement of contractility, the mucosa was removed from the intestinal segments. Segments were then cut into rectangular strips oriented towards the longitudinal axis of the circular muscle cell layer. The length of the strips was equal to the circumference of the intestine, and width was 2-3 mm. Muscle contraction was measured isometrically under a resting tension of $5 \mathrm{mN}$. At the end of the experiments the muscle strips were blotted with filter paper and weighed on an analytical balance. The contractile responses to the agonists are expressed as absolute force $(\mathrm{mN}$ per mg tissue wet weight).

Abbreviations: ETB (-/-|R, endothelin ETB receptor null rat; RT-PCR, reverse transcription-polymerase chain reaction; EFS, electrical field stimulation. 
A

$\mathrm{ETB}(+/+)$

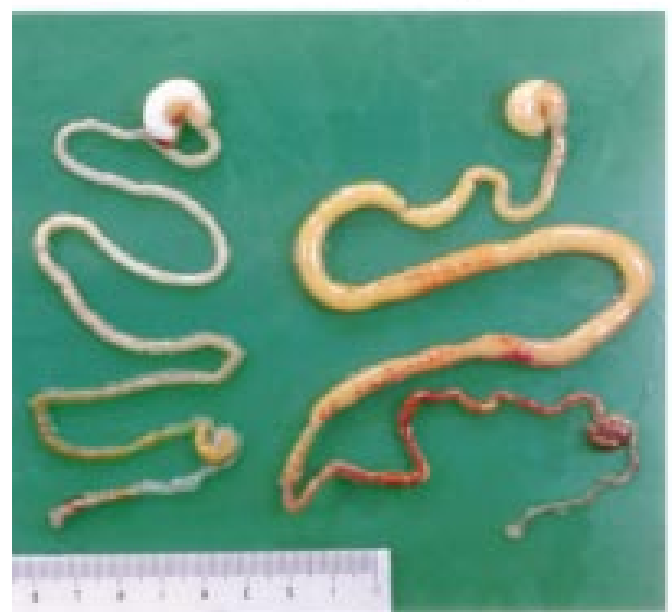

B
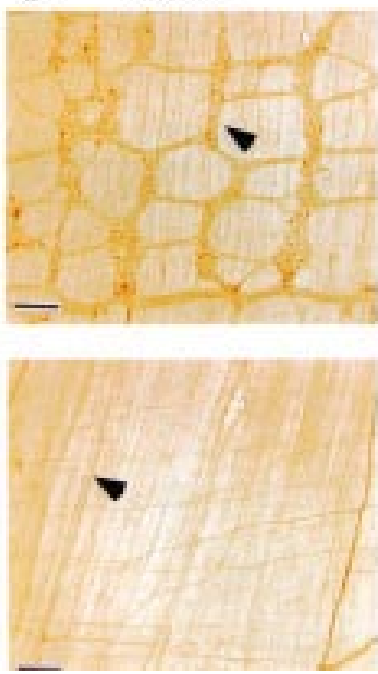
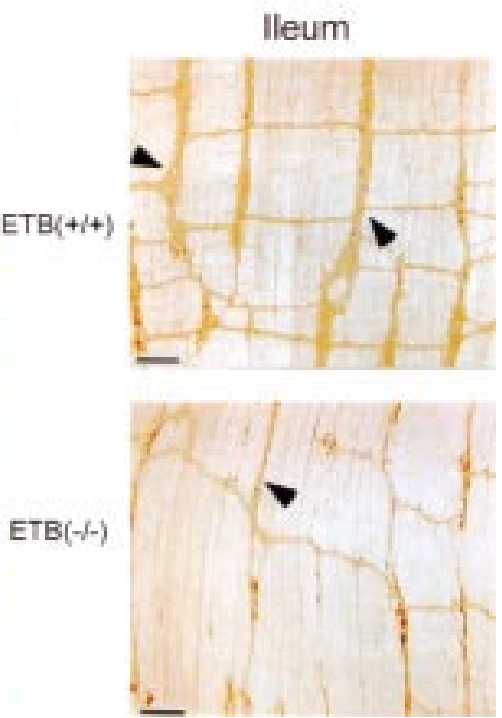

Figure 1 (A) Dissection of the entire gastrointestinal tract. The severe intestinal enlargement is shown in the homozygous endothelin ETB receptor null rat $(E T B(-/-) R)$ compared with the homozygous wild type $E T B(+/+)$ R. Dilation of the proximal ileum was observed in the intestine of the homozygous ETB $-/-\mid R$. (B) Whole mount preparations of the colon and proximal ileum from the ETB(+/+)R and ETB(-/-)R stained with anti-PGP9.5 antibody. The ETB(+/+)R shows a close regular pattern of the plexus (arrowheads) whereas in the ETB(-/-)R only a nerve bundle (arrowhead) is observed (colon), and the myenteric plexus (arrowhead) appears to have a decreased number of ganglia and to be somewhat stretched (ileum). Bar $=100 \mu \mathrm{m}$.

\section{Histological examination}

Segments of the intestine isolated from the $\operatorname{ETB}(+/+) \mathrm{R}$ and ETB $(-/-) \mathrm{R}$ were fixed in $2.5 \%$ glutaraldehyde in $0.1 \mathrm{M}$ phosphate buffer (pH7.4), post fixed with $1 \% \mathrm{OsO}_{2}$, dehydrated through graded ethanol, and embedded in Epon 812. Semi-thin sections were stained with $0.1 \%$ toluidine blue in $0.1 \mathrm{M}$ phosphate buffer.

For immunohistochemistry, whole mount preparations of the enteric nerve elements, terminal ileum, and colon from the $\operatorname{ETB}(+/+) \mathrm{R}$ and $\operatorname{ETB}(-/-) \mathrm{R}$ were fixed in $4 \%$ paraform aldehyde in 0.1 M phosphate buffer ( $\mathrm{pH}$ 7.4). The muscle layers were separated and washed in phosphate buffered saline (pH 7.5). Samples were incubated with anti-PGP9.5 polyclonal antibody (Ultraclone, UK; 1:8000) followed by incubation with antirabbit IgG conjugated with biotin (Vector, USA; 1:200). Immunohistochemistry was accomplished with an avidinbiotin complex system (Vectastaine ABC kit; Vector), and the reaction products were developed by $0.03 \%$ diaminobenzidine and $0.005 \% \mathrm{H}_{2} \mathrm{O}_{2}$ in $0.05 \mathrm{M}$ Tris $\mathrm{HCl}$ buffer ( $\mathrm{pH} 7.6$ ).

\section{Semiquantitative RT-PCR}

The oligonucleotide primers for the ETA receptor were designed based on data from the cDNA database (NM 012550) by selecting specific amino acid sequences from the cDNA database for the ETB receptor (X 57764). The forward and reverse primers for the ETA receptor were designed as $5^{\prime}$-ATG AGA TGG ATA AGA ACC-3', and 5'-CCA TTC ATG GGG ACC CAG G-3', respectively. The suitable size of the reverse transcription-polymerase chain reaction (RT-PCR) product for the ETA receptor is $205 \mathrm{bp}$. The oligonucleotide primers for the ETB receptor were designed considering the deletion site of ETB $(-/-) \mathrm{R}$, as described previously. ${ }^{10}$ The forward and reverse primers for the ETB receptor were designed as 5'-GCG TCG ACG CCA CCC ACT AAG ACC TCC-3' and 5'-CAT CAA AAC CTA TGG CTT CAG GGA CAG-3', respectively. The suitable size of the synthesised cDNA for ETB receptor is $586 \mathrm{bp}$. In the ETB $(-/-)$ R however a suitable product cannot be obtained because of the deleted mutation corresponding to the first and second transmembrane domains of the ETB receptor. ${ }^{10}$ The oligonucleotide primers for GAPDH were 5 '-TCC CTC AAG ATT GTC AGC AA-3' (forward primer) and 5'-AGA TCC ACA ACG GAT ACA TT-3' (reverse primer), and the theoretical size of the RT-PCR product for GAPDH is $308 \mathrm{bp}$. The PCR products obtained from 35-50 cycles (five cycle interval) were electrophoresed onto $2 \%$ agarose gel containing $0.1 \%$ ethidium bromide and were detected using a UV transilluminator. The densitometric intensity at 45 cycles was quantified by NIH imaging. The quantitative results are expressed as the ratio of the densitometric intensity of GAPDH.

\section{Statistics}

The results of the experiments are expressed as mean (SEM). The unpaired Student's $t$ test was used for statistical analysis of the results; $p$ values less than 0.05 were considered to be significant.

\section{RESULTS}

\section{General biological features of ETB(-/-)R}

The ETB(-/-)R had a unique appearance, with their almost white coat (caused by a reduced number of pigment cells in the coat) and abdominal distension. The ETB $(+/+) \mathrm{R}$ had a black coat limited to the head and part of the body. The physique of the $\operatorname{ETB}(-/-) \mathrm{R}$ was poor with severe emaciation and growth retardation. The ETB $(-/-) \mathrm{R}$ hair was lustreless and rough. The death rate of the $\operatorname{ETB}(-/-) \mathrm{R}$ was significantly greater than that of the $\operatorname{ETB}(+/+) \mathrm{R}$. The shortest life span of the $\operatorname{ETB}(-/-) \mathrm{R}$ in the present study was three days and the longest was 34 days (mean 18.1 days).

Figure $1 \mathrm{~A}$ shows the abdominal dissection and digestive tract from the stomach to the anus. The ETB(-/-) R had intestinal dilation in the same location with abdominal distention. In the ETB(-/-) R, a constricted bowel region was observed throughout the colon, including the caecum and lower part of the ileum, followed by a dilated region with faecal stasis. Therefore, megaileum was usually observed. These pathological features resemble those of human long segment Hirschsprung's disease; they appeared to be more severe than those of general short segment Hirschsprung's disease in which the constricted portion of the bowel region is generally in the colon.

Figure 1B shows the structure of the myenteric plexus in the colon and ileum of the $\operatorname{ETB}(+/+) \mathrm{R}$ and $\operatorname{ETB}(-/-) \mathrm{R}$. Although there were some individual differences, the myenteric plexus in the colon and ileum of the $\operatorname{ETB}(+/+) \mathrm{R}$ showed a similar shape and size of ganglia with a regular meshwork pattern (fig 1B). In the dilated (proximal) portion 
A Proximal ileum (dilated)

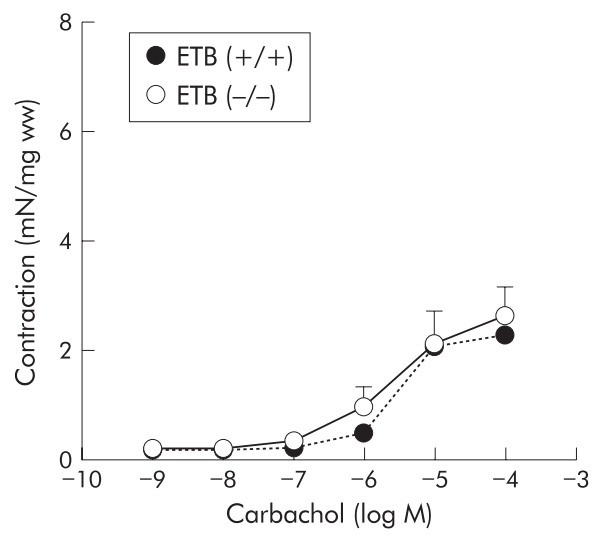

B Distal ileum (constricted)

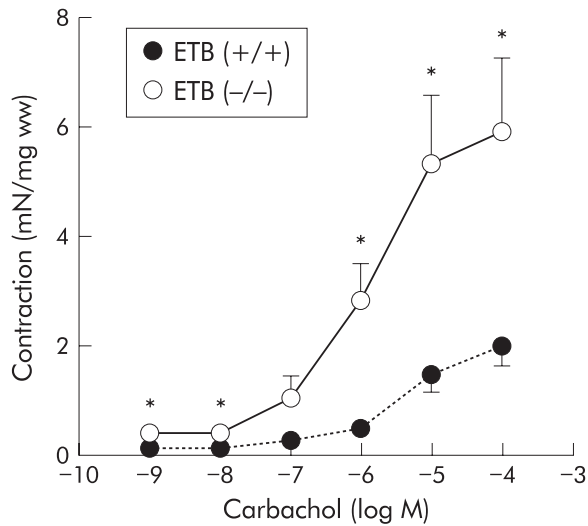

Figure 2 Contractile effect of carbachol on the proximal (A) and distal (B) parts of the ileum in the homozygous endothelin ETB receptor null rat (ETB(-/-)R) compared with the homozygous wild type ETB(+/+)R. Contractile responses are expressed in $\mathrm{mN}$ per $\mathrm{mg}$ tissue wet weight $(\mathrm{mN} / \mathrm{mg} \mathrm{ww})$. Each point represents the mean (SEM) of eight experiments. Significantly different from ETB(+/+)R: ${ }^{*} p<0.05$.

of the $\operatorname{ETB}(-/-) \mathrm{R}$ ileum however the myenteric plexus appeared to be decreased in density and stretched in the shape of meshwork compared with that in the $\operatorname{ETB}(+/+) \mathrm{R}$ ileum (fig 1B). In the constricted (distal) part of the ETB(-/-)R colon, the myenteric ganglia were completely absent, and only some extrinsic nerve fibres or bundles were observed (fig 1B).

\section{Contractions}

Carbachol (0.001-100 $\mu \mathrm{M})$, a muscarinic receptor agonist, produced concentration dependent contractions both in the constricted (distal) and dilated (proximal) portions of ileum from the $\operatorname{ETB}(+/+) \mathrm{R}$ and $\operatorname{ETB}(-/-) \mathrm{R}$ (fig 2). The contractions generated by carbachol in the constricted (distal) part of the ETB(-/-)R ileum ( $100 \mu M$ carbachol: 5.88 (1.39) mN/mg ww; $\mathrm{n}=8$ ) were significantly greater than those of the corresponding part of the $\operatorname{ETB}(+/+$ ) ileum ( 1.99 (0.39) $\mathrm{mN} / \mathrm{mg} \mathrm{ww}$; $\mathrm{n}=8$ ) (fig $2 \mathrm{~B})$. However, the contractile responses induced by carbachol in the dilated (proximal) parts of the ETB(-/-)R ileum $(2.60(0.64)$ $\mathrm{mN} / \mathrm{mg} \mathrm{ww} ; \mathrm{n}=8$ ) were almost the same as those of the corresponding part of the $\operatorname{ETB}(+/+) \mathrm{R}(2.25(0.19) \mathrm{mN} / \mathrm{mg}$ ww; $\mathrm{n}=8$ ) (fig 2A). The constricted (distal) ileum in the ETB $(-/-) \mathrm{R}$ showed greater contractility than the dilated (proximal) ileum.

Addition of $\mathrm{KCl}(5.4-72.7 \mathrm{mM})$ produced concentration dependent contractions in both the constricted (distal) and dilated (proximal) ileum from the $\operatorname{ETB}(+/+) \mathrm{R}$ and $\operatorname{ETB}(-/-) \mathrm{R}$ (fig 3). The amplitude of the contractions generated by $\mathrm{KCl}$ of constricted (distal) parts of the ETB(-/-)R ileum (72.7 mM KCl: $3.87(0.99) \mathrm{mN} / \mathrm{mg} \mathrm{ww} ; \mathrm{n}=8$ ) was significantly greater than that
A Proximal ileum (dilated)

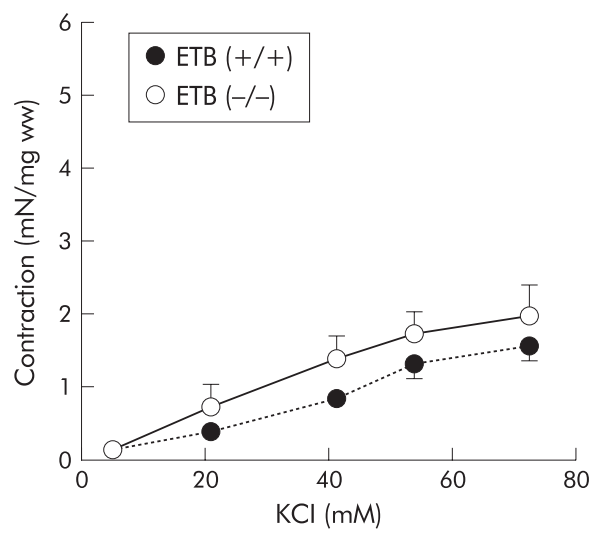

B Distal ileum (constricted)

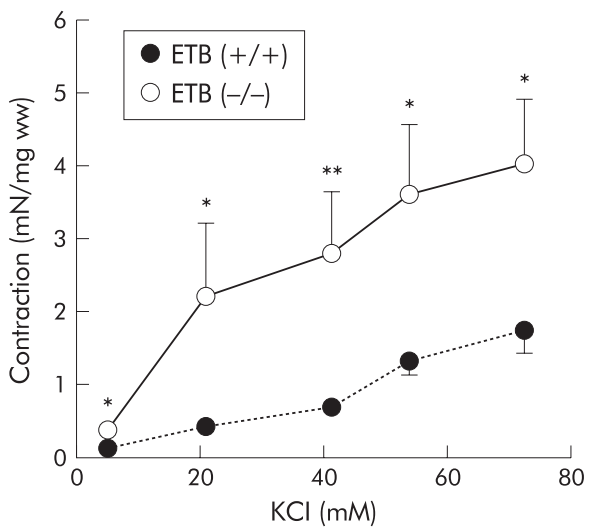

Figure 3 Contractile effects of $\mathrm{KCl}$ on the proximal $(\mathrm{A})$ and distal (B) parts of the ileum in the homozygous endothelin ETB receptor nul rat $(\mathrm{ETB}(-/-) \mathrm{R})$ compared with the homozygous wild type $\mathrm{ETB}(+/+) \mathrm{R}$. Contractile responses are expressed in $\mathrm{mN}$ per $\mathrm{mg}$ tissue wet weight $(\mathrm{mN} / \mathrm{mg} \mathrm{ww})$. Each point represents the mean (SEM) of eight experiments. Significantly different from the ETB $++/+\mid)$ : ${ }^{*} p<0.05$, $* * p<0.01$.

of corresponding parts of the $\mathrm{ETB}(+/+) \mathrm{R}$ ileum $(1.75(0.30)$ $\mathrm{mN} / \mathrm{mg} \mathrm{ww} ; \mathrm{n}=8$ ) (fig 3B). However, the contractile responses induced by $\mathrm{KCl}$ in the dilated (proximal) parts of the ileum in the ETB(-/-)R ileum ( $1.86(0.41) \mathrm{mN} / \mathrm{mg} \mathrm{ww}$; $=8$ ) were almost the same as those of corresponding parts of the $\mathrm{ETB}(+/+) \mathrm{R}$ ( $1.56(0.22) \mathrm{mN} / \mathrm{mg} w w ; n=8)$ (fig $3 \mathrm{~A})$. The contraction generated by $\mathrm{KCl}$ in the constricted (distal) part of the ETB(-/-)R ileum was greater than that of the dilated (proximal) part.

Addition of endothelin-1 (0.1-3×100 nM), a non-selective agonist of endothelin ETA and ETB receptors, produced concentration dependent contractions in both the constricted (distal) and dilated (proximal) ileum from the ETB $(+/+)$ R and ETB $(-/-)$ R (fig 4 ). The amplitude of contractions generated by endothelin-1 of the constricted (distal) parts of the ETB(-/-)R ileum (100 nM endothelin-1: 7.45 (1.76) $\mathrm{mN} / \mathrm{mg}$ ww; $\mathrm{n}=9$ ) was significantly higher than that of the corresponding parts of the ETB $(+/+) \mathrm{R}$ ileum ( $1.21(0.31) \mathrm{mN} / \mathrm{mg} w w ; n=10)$ (fig 4B). In addition, the contractile responses induced by endothelin- 1 at higher concentrations (10-100 nM) in the dilated (proximal) parts of the ileum in the ETB(-/-)R (100 nM endothelin-1: 2.84 (0.75) mN/mg ww; $\mathrm{n}=9$ ) were also significantly higher than those of the corresponding parts of the $\operatorname{ETB}(+/+) \mathrm{R}(0.67(0.18) \mathrm{mN} / \mathrm{mg}$ ww; $\mathrm{n}=10)$ (fig $4 \mathrm{~A})$. The constricted (distal) ileum of the ETB $(-/-) \mathrm{R}$ showed greater contractility than the dilated (proximal) ileum.

Contractions induced by $10 \mu \mathrm{M}$ carbachol in the muscle strips of the constricted regions (colon, caecum, and distal ileum) from the ETB(-/-)R were significantly greater than those of the corresponding parts of the $\operatorname{ETB}(+/+) \mathrm{R}(8.04$ 
A Proximal ileum (dilated)

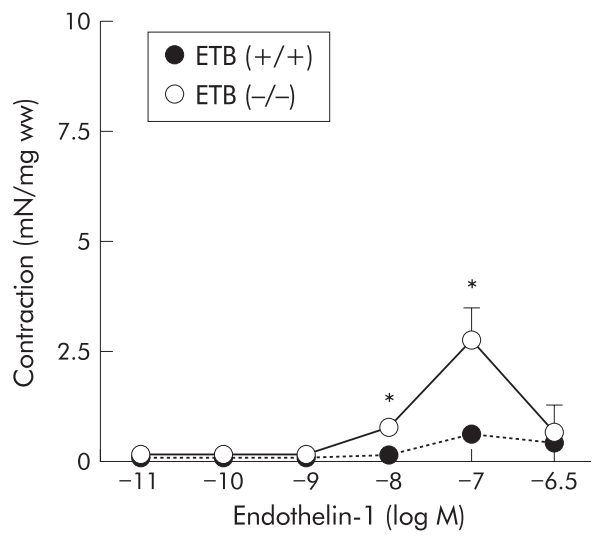

B Distal ileum (constricted)

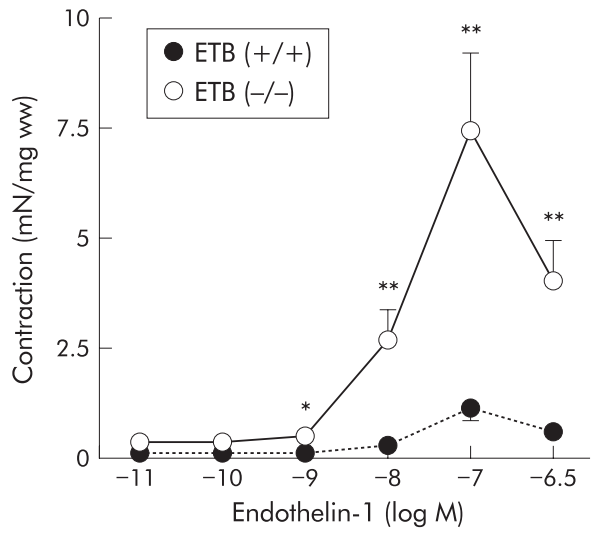

Figure 4 Contractile effects of endothelin-1 on the proximal (A) and distal (B) parts of the ileum in the homozygous endothelin ETB receptor null rat (ETB(-/-)R) compared with the homozygous wild type ETB(+/+)R. Contractile responses are expressed in $\mathrm{mN}$ per $\mathrm{mg}$ tissue wet weight $(\mathrm{mN} / \mathrm{mg} \mathrm{ww})$. Each point represents the mean (SEM) of nine or 10 experiments. Significantly different from the $\operatorname{ETB}(+/+) \mathrm{R}:{ }^{*} p<0.05,{ }^{* *} p<0.01$.

$(1.42) \vee 4.22(0.56) \mathrm{mN} / \mathrm{mg} \mathrm{ww} ; 7.79(1.30) \vee 4.84(0.54)$ $\mathrm{mN} / \mathrm{mg} \mathrm{ww}$, and 5.35 (1.36) v $1.46(0.33) \mathrm{mN} / \mathrm{mg} \mathrm{ww}$, respectively; $n=9-11$ ) whereas contractions of muscle strips of the dilated ileum and jejunum from the ETB $(-/-) \mathrm{R}$ were the same as those of the corresponding parts of the $\operatorname{ETB}(+/+) \mathrm{R}(2.08$ (0.61) v $2.01(0.13) \mathrm{mN} / \mathrm{mg} \mathrm{Ww}$ and $3.17(0.48) v 3.44(0.37)$ $\mathrm{mN} / \mathrm{mg} \mathrm{ww}$, respectively; $\mathrm{n}=9-11$ ) (fig 5)

\section{Possible involvement of inhibitory substances}

The ETB $(-/-) \mathrm{R}$ has few nerves in the aganglionic segments but the wild type has normal enteric neurones present. Regarding the increased contractility in $\operatorname{ETB}(-/-) \mathrm{R}$, it is possible that release of transmitters such as nitric oxide and ATP could inhibit the contractility of the intestine in $\operatorname{ETB}(+/+) \mathrm{R}$ more than ETB(-/-)R. Contraction induced by carbachol (0.1 $\mu \mathrm{M})$ was augmented following addition of L-NAME (100 $\mu \mathrm{M})$ in the proximal and distal ileum of $\operatorname{ETB}(+/+)$ and ETB $(-/-)$ rats. However, we observed no significant differences between responses in $\operatorname{ETB}(+/+)$ and $\operatorname{ETB}(-/-)$, which implies that nitric oxide may not be involved in the increased contractility in $\mathrm{ETB}(-/-)$ rats. In contrast, suramine $(300 \mu \mathrm{M})$, a non-competitive agonist of $\mathrm{P}_{2 \mathrm{X}}$ and $\mathrm{P}_{2 \mathrm{X}}$ receptors, was unable to modify the carbachol induced contractions in the ileal strips, indicating that ATP is not responsible for the increased contractility of the ETB(-/-)R intestine.

\section{Changes in the ETA receptor}

RT-PCR analysis of RNA extracted from the muscle tissue of $\operatorname{ETB}(+/+) \mathrm{R}$ and ETB(-/-) R was carried out. As shown in fig 6,

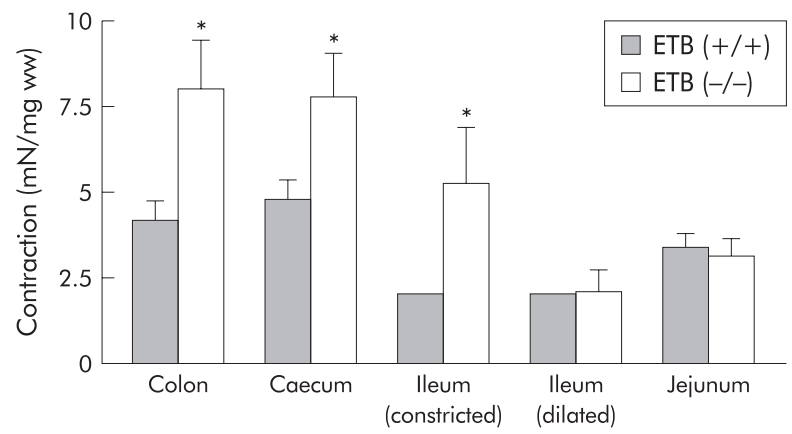

Figure 5 Comparison of the contractile effects of $10 \mu \mathrm{M}$ carbachol on intestinal smooth muscle of the homozygous endothelin ETB receptor null rat (ETB(-/-)R) compared with the homozygous wild type ETB(+/+)R. Contractile responses are expressed in $\mathrm{mN}$ per $\mathrm{mg}$ tissue wet weight ( $\mathrm{mN} / \mathrm{mg} \mathrm{ww})$. Each point represents the mean (SEM) of 9-11 experiments. Significantly different from the $\mathrm{ETB}(+/+) \mathrm{R}:{ }^{*} \mathrm{p}<0.05$.

expression of the RT-PCR product encoding the housekeeping gene GAPDH (308 bp) was identical in controls and ETB $(-/-)$ R. ETB receptor ( $586 \mathrm{bp}$ ) mRNAs were strongly expressed in the normal ETB $(+/+)$ R. It has been reported that a 301 bp region intervening between direct repeat sequences was deleted in the ETB $(-/-) \mathrm{R}$, and that the deletion produces various transcripts due to aberrant splicing..$^{10}$ Consistent with this observation, we observed two bands in an area approximately 300 bp shorter than in normal rats. In contrast, ETA receptor (205 bp) mRNAs were expressed both in $\operatorname{ETB}(+/+) \mathrm{R}$ and $\operatorname{ETB}(-/-) \mathrm{R}$, with no significant difference between the two. There was also no significant difference in ETA receptor mRNA between the constricted (distal) and dilated (proximal) ileum from the ETB $(-/$ $-)$ R (ETA mRNA/GAPDH mRNA: distal ileum in ETB $(+/+) \mathrm{R}$ 0.41 (0.09); distal ileum in $\operatorname{ETB}(-/-) \mathrm{R} 0.63$ (0.2); proximal ileum in $\mathrm{ETB}(-/-) \mathrm{R} 0.61$ (0.08); $\mathrm{n}=3$ each).

\section{Histology}

A histological profile of thickness of the smooth muscle layer can be obtained by determining the number of piling smooth muscle cells of each muscle layer of the ETB $(+/+)$ R and ETB $(-/$ $-) R$. In general, both the longitudinal and circular smooth muscle layers were thicker in the ETB(-/-) R than in the ETB $(+/+) \mathrm{R}$ although the diameter of each smooth muscle cell around the nuclear region was not different, as shown in fig 7A.

To obtain more numerical data on the thickness of the smooth muscle layer, the smooth muscle cells in the circular or longitudinal muscle layers were counted in the ETB $(-/-) \mathrm{R}$ and $\operatorname{ETB}(+/+) \mathrm{R}$ on the longitudinal or circular section, respectively. As shown in fig 7B, the number of cells piled in the longitudinal smooth muscle layers of both the caecum and colon of the $\operatorname{ETB}(-/-) \mathrm{R}$ was significantly greater than that in the corresponding muscle layers of the $\operatorname{ETB}(+/+)$ R. However, the number of cells in the circular smooth muscle in the proximal ileum (dilated segment) and that of longitudinal smooth muscle of the caecum (constricted segment) of the ETB $(-/-) \mathrm{R}$ was not statistically different from that of the $\operatorname{ETB}(+/+) \mathrm{R}$.

\section{DISCUSSION}

In Hirschsprung's disease obstruction of the gut creates a distended oral gut followed by a constricted anal portion similar to a megacolon. The distended oral side is a ganglionic segment where the number of enteric neurones is gradually reduced and continues to the constricted aganglionic segment. This pattern was confirmed in the ETB $(-/-)$ R. The constricted gut of the ETB(-/-)R was long and extended to the terminal ileum, resulting in megaileum (fig 1). Due to these severe gut conditions, the average lifespan was only 18.1 days. 


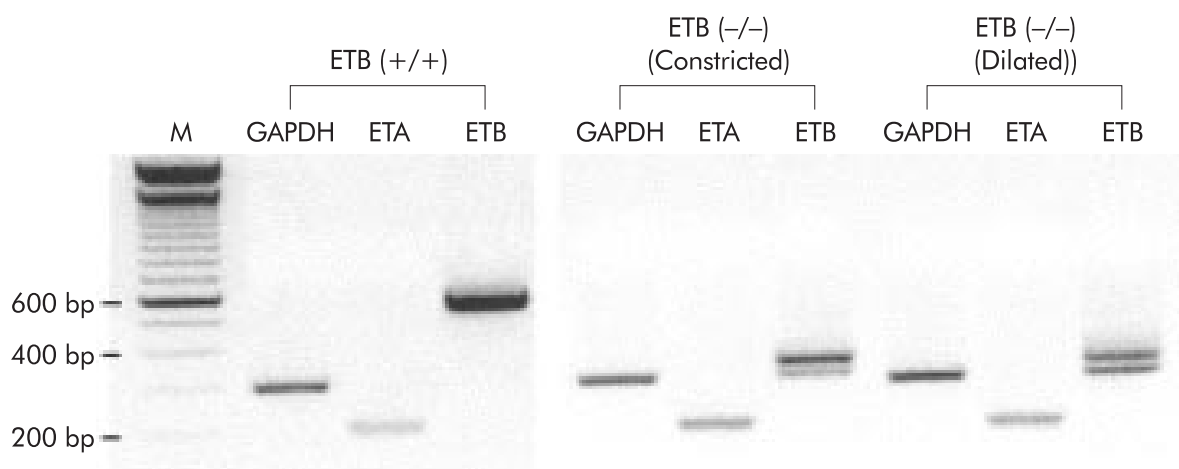

Figure 6 Expression of ETA and ETB receptor mRNAs in the ileal smooth muscle of the homozygous endothelin ETB receptor null rat $(E T B(-/-\mid R)$ compared with the homozygous wild type ETB(+/+)R. Typical results after 45 cycles of reverse transcription-polymerase chain reaction (RT-PCR) are shown. Suitable sizes of RT-PCR products for GAPDH, ETA receptor, and ETB receptor are 308 bp, 205 bp, and 586 bp, respectively. Note the two bands in an area approximately 300 bp shorter than in normal rats in the ETB(-/-)R for the ETB receptor.
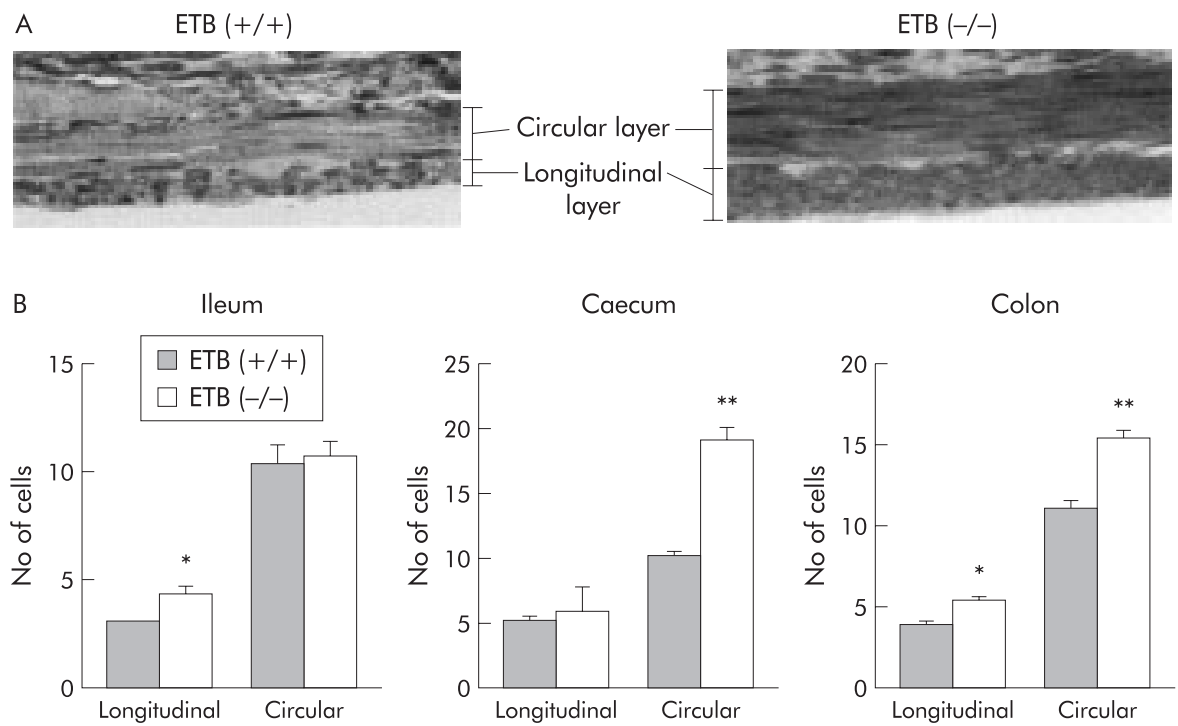

Figure 7 Thickness of the muscle layer indicated by the number of piling cells in the muscle layers of the homozygous endothelin ETB receptor null rat (ETB(-/-)R) compared with the homozygous wild type ETB(+/+)R. (A) Cross section of the caecum in the ETB $(+/+) R$ and ETB(-/-)R stained with toluene blue. (B) Number of smooth muscle cells in the lower part of the ileum (distended segment), caecum, and colon (constricted segments) of the ETB $(+/+) R$ and the ETB $(-/-)$. Each column represents the mean (SEM) of three experiments. ${ }^{*} p<0.05,{ }^{* *} p<0.01$.

This animal model therefore corresponds to long segment Hirschsprung's disease in humans.

Constriction of the aganglionosis segment has been explained as being characterised by a lack of an inhibitory nerve supply such as nitric oxide neurones ${ }^{15-17}$ and proliferation of extrinsic nerve fibres-that is, cholinergic neurones. ${ }^{18}{ }^{19}$ Predominance of a contractile nerve supply and a scant number of inhibitory neurones seems to cause the characteristic constriction. However, the distribution of nerve terminals was significantly more sparse in the constricted segment than in the normal segment, ${ }^{18}{ }^{19}$ suggesting poor innervation of the muscle layer in the constricted portion. Therefore, the neurogenic obstruction described above does not fully explain the abnormal constriction and pathophysiology of the disease. These results strongly suggest that a myogenic mechanism is involved in the constricted gut.

In the present study, we observed that the absolute contractile force in response to carbachol in the distal ileum of the ETB $(-/-) \mathrm{R}$ without ganglia (constricted) was larger than that of the $\operatorname{ETB}(+/+)$ R. In contrast, the proximal ileum of the ETB(-/-)R intestine with ganglia (dilated) showed an ampli- tude of force similar to that of the ETB $(+/+)$ R. In addition, the constricted distal ileum had greater contractility than the dilated proximal ileum in the ETB(-/-) R. We also compared contractility to carbachol in the entire intestinal tract and found that the lower part of the intestines with no ganglia (distal ileum, caecum, and colon) induced greater contraction than the upper part of the intestine with ganglia (proximal ileum and jejunum). These results suggest that the increased contractility observed in the $\operatorname{ETB}(-/-) \mathrm{R}$ intestine is closely associated with the absence of ganglia in the intestine.

Augmented contractility was demonstrated in the present study when the muscle was treated with a non-cholinergic agonist, endothelin-1, or with high $\mathrm{K}^{+}$simply increasing the intracellular $\mathrm{Ca}^{2+}$ concentrations. These results suggest that the change in contractility is attributable to changes other than just membrane associated reactions. There are several possibilities for the increased contractility of the intestine in the $\operatorname{ETB}(-/-)$ R. One is that the absence of propulsive motor activity, mediated by ganglial dysfunction, upregulates the contractility of smooth muscle cells. It is also probable that inflammatory reactions may affect the contractility of smooth 
muscle cells in the $\operatorname{ETB}(-/-) \mathrm{R}$, as enterocolitis is frequently observed in this model animal.

Consistent with our results, Hillermeier and Biancani ${ }^{20}$ have reported that active force generated in vitro in the colonic smooth muscle in the mutant Hirschsprung mouse model is greater than that in wild type mice. However, Siegman and colleagues $^{21}$ have failed to confirm these phenomena in which there were no differences in the force per cross sectional area of permeabilised muscles maximally activated in high concentrations of $\mathrm{Ca}^{2+}$. These findings suggest that the functional hypertrophy observed in the Hirschsprung mouse model is attributable to mechanisms other than activation of contractile elements, which is inconsistent with our findings in rats. Siegman and colleagues ${ }^{21}$ have further reported that there is an increase in the shortening velocity in the colon of obstructed mice, an increase that is associated with changes in the contractile elements such as isoforms of myosin and actin.

In our study of smooth muscle histology, we found that the thickness of the smooth muscle layer in the portion of intestine with no ganglia in the $\operatorname{ETB}(-/-) \mathrm{R}$ was greater than that of corresponding parts in the $\mathrm{ETB}(+/+) \mathrm{R}$. Furthermore, the number of smooth muscle cells comprising both the circular and longitudinal muscle layers increased in the ETB $(-/-)$ R. These results were different from the observation in the Hirschsprung mouse model that the thickness of the circular smooth muscle layer in constricted intestine is the same as that in obstructed and control mice. ${ }^{20}$ This difference is probably related to the length of the aganglionic segment; the Hirschsprung mouse model has short constricted segments (only a terminal colon) that lack enteric ganglia.

The question is then raised as to how the muscle might be exposed to the agonists that were utilised to demonstrate hyperactivity of the gut in the aganglionic preparations. It has been reported that in normal mice, electrical field stimulation (EFS) induces an initial decrease followed by an increase in basal tone whereas EFS induces only contraction in the mutant Hirschsprung mouse model, and that there is no significant difference in the amplitude of contractions in these preparations. ${ }^{22}$ An excitatory response to EFS has also been demonstrated in the aganglionic segment of intestine in ETB(-/-)R. ${ }^{23}$ These contractile responses to EFS appear to be cholinergic as they are blocked by atropine. Similar atropine sensitive contractions have been demonstrated in Hirschsprung's patients. ${ }^{24}$ Because extrinsic nerve innervation is intact in the aganglionic intestine ${ }^{18}{ }^{19}$ acetylcholine may be released and thus related to maintenance of an elevated muscle tone.

Both ETA and ETB receptors are responsible for activation of gastrointestinal motility. ${ }^{25}$ Although the contractility of the dilated (proximal) ileum to carbachol or high $\mathrm{K}^{+}$does not differ between $\operatorname{ETB}(+/+) \mathrm{R}$ and $\operatorname{ETB}(-/-) \mathrm{R}$, contraction due to endothelin- 1 in the ETB(-/-)R was significantly greater than that in $\operatorname{ETB}(+/+) \mathrm{R}$, implying that the ETA receptor is upregulated in the $\operatorname{ETB}(-/-) \mathrm{R}$. In the present study, we analysed the level of ETA receptor mRNA by RT-PCR. However, we observed no change in the expression of mRNA levels. These results suggest that the downstream signal-transduction pathway after ETA receptor stimulation may be upregulated by a deficiency of the ETB receptor.

It has been considered that the absence of peristalsis in response to deficiencies in the number of ganglion cells may cause the intestinal obstruction found in Hirschsprung's disease. Our findings suggest that as an additional mechanism, increased contractility of smooth muscle and increased thickness of the intestinal muscular wall may contribute to the constriction of intestine in Hirschsprung's disease. Thus the absence of peristalsis and the morphological and functional hypertrophy in the intestine may promote the intestinal obstruction in Hirschsprung's disease. The present study also indicates that the results obtained in mutant rats (long segment model) are different in terms of some of the abovementioned functional and histological features from those obtained in mutant mice (short segment model).

\section{ACKNOWLEDGEMENTS}

This work was supported by a Grant-in-Aid for Scientific Research from the Ministry of Education, Culture, and Science, Japan, Human Science Foundation, Yakult Bio-Science Foundation, Takeda Science Foundation, and a Program for Promotion of Basic Research Activities for Innovative Biosciences (BRAIN).

\section{Authors' affiliations}

K-J Won, M Mitsui-Saito, M Hori, K Sato, T Suzuki, H Ozaki, H Karaki, Department of Veterinary Pharmacology, Graduate School of Agriculture and Life Sciences, The University of Tokyo, Bunkyo-ku, Yayoi 1-1-1, Tokyo 113-8657, Japan

S Torihashi, Department of Anatomy and Cell Biology, Nagoya University Graduate School of Medicine, Tsurumai-ku, Nagoya 466-8550, Japan

\section{REFERENCES}

1 Skinner MA. Hirschsprung's disease. Curr Prob/ Surg 1996;33:389-460.

2 Passarge E. The genetics of Hirschsprung's disease. Evidence for heterogeneous etiology and a study of sixty-three families. N Engl J Med 1967; 276: 138-43.

3 Ehrenpreis T. Hirschsprung's disease. Dig Dis 1971;16:1032-52.

4 Badner JA, Sieber WK, Garver KL, et al. A genetic study of Hirschsprung's disease. Am J Hum Genet 1990;46:568-80.

5 Kernkamp HCH, Kanning HH. Primary megacolon (Hirschsprung's disease) in swine. North Am Vet 1955;36:642-3.

6 Metallinos DL, Bowling AT, Rine J. A missense mutation in the endothelin-B receptor gene is associated with lethal white foal syndrome: an equine version of Hirschsprung's disease. Mamm Genome 1998;9:426-31.

7 Ikadai H, Fujita H, Agematsu Y, et al. Observation of congenital aganglionosis rat (Hirschsprung's disease) and its genetical analysis. Cong Anom 1979;19:31-6.

8 Ceccherini I, Zhang AL, Matera I, et al. Intestinal deletion of the endothelin-B receptor gene in the spotting lethal (sl) rat. Hum Mol Genet 1995:4:2089-96.

9 Karaki H, Mitsui-Saito M, Takimoto $M$, et al. Lack of endothelin ETB receptor binding and function in the rat with a mutant ETB receptor gene. Biochem Biophys Res Commun 1996;222:139-43.

10 Kunieda T, Kumagai T, Tsuji T, et al. A mutation in endothelin-B receptor gene causes myenteric aganglionosis and coat color spotting in rats. DNA Res 1996;3:101-5.

11 Coventry S, Yost C, Palmiter RD, et al. Migration of ganglion cell precursors in the ileoceca of normal and lethal spotted embryos, a murine model for Hirschsprung's disease. Lab Invest 1994;71:82-93.

12 Ikadai H, Suzuki K, Fujita $\mathrm{H}$, et al. Animal models of human disease: Hirschsprung's disease. Comput Pathol Bull 1981;13:3-4.

13 Horie H, Ikadai, H, Iwasaki I, et al. Pathologic studies on newly established congenital aganglionosis rat in Japan. J Jpn Soc Pediatr Surg 1980;16:549-60.

14 Nagahama M, Ozaki T, Hama K. A study of the myenteric plexus of the congenital aganglionosis rat (spotting lethal). Anat Embryol $1985 ; 171: 285-96$

15 Larsson LT, Malnfors G, Wahlested C, et al. Hirschsprung's disease: a comparison of the nervous control of ganglionic and aganglionic smooth muscle in vitro. J Pediatr Surg 1987;22:431-5.

16 Bealer JF, Natuzzi ES, Flake AW, et al. Effect of nitric oxide on the colonic smooth muscle of patients with Hirschsprung's disease. J Pediatr Surg 1994;29:1025-9.

17 Larsson LT, Shen Z, Ekblad E, et al. Lack of neuronal nitric oxide synthase in nerve fibers of aganglionic intestine: a clue to Hirschsprung's disease. J Pediatr Gastroenterol Nutr 1995;20:49-53.

18 Yamataka A, Miyano T, Okazaki T, et al. Correlation between extrinsic nerve fibers and synapses in the muscle layers of bowels affected by Hirschsprung's disease. J Pediatr Surg 1992;27:1213-16.

19 Yamataka A, Nagaoka, I, Miyano T, et al. Quantitative analysis of neuronal innervation in the aganglionic bowel of patients with Hirschsprung's disease. J Pediatr Surg 1995;30:260-73.

20 Hillemeier C, Biancani P. Mechanical properties of obstructed colon in a Hirschsprung's model. Gastroenterology 1990;99:995-1000.

21 Siegman MJ, Butler TM, Mooers SU, et al. Hypertrophy of colonic smooth muscle: contractile proteins, shortening velocity, and regulation. Am J Physiol 1997;272:G1571-80.

22 Chakder S, McHugh KM, Rattan S. Inhibitory neurotransmission in lethal spotted mutant mice: a model for Hirschsprung's disease. Gastroenterology 1997;112:1575-85

23 Kubota $M$, Ito $Y$, Taguchi T, et al. Regional differences in the pattern of neurogenic responses in the aganglionic colon from congenitally aganglionic rats. J Pediatr Surg 1989:24:911-19.

24 Kamimura T, Kubota $M$, Suita $S$, et al. Functional innervation of the aganglionic segment in Hirschsprung's disease-a comparison of the short- and long-segment type. J Pediatr Surg 1997;32:673-7.

25 Miasiro N, Karaki H, Paiva ACM. Heterogenous endothelin receptors mediate relaxation and contraction in the guinea-pig ileum. Eur $J$ Pharmacol 1995;285:247-54. 